\title{
ОСОБЛИВОСТІ СПЕЦІАЛЬНО-КРИМІНОЛОГІЧНОГО ЗАПОБІГАННЯ ЗЛОЧИНАМ У СФЕРІ ДІЯЛЬНОСТІ КРЕДИТНИХ СПІЛОК В УКРАЇНІ
}

Купрієнко В. М.

у статmі надано характеристику ринку фінансових послуг, на основі чого виокремлено типові правопорушення, що вчинюються при провадженні діяльності кредитними спілками. 3 метою виявлення визначених правопорушень автором надано характеристику діяльності підрозділів із захисту економіки Національної поліції щодо своєчасного викриття зловживань, які вчиняються посадовими особами кредитної спілки, перевірки та аналізу їх діяльності.

у статті надано характеристику ринку фінансових послуг, виокремлено типові правопорушення, що вчинюються при провадженні діяльності кредитними спілками. 3 метою виявлення визначених правопорушень автором надано характеристику діяльності підрозділів із захисту економіки Національної поліції щодо своєчасного викриття зловживань, які вчиняються посадовими особами кредитної спілки, перевірки та аналізу їх діяльності.

Hamenep спостерігається слабкий контроль із боку держави за функціонуванням кредитних спілок, що є одним із чинників провадження ними незаконної діяльності. За даними Національної комісії, яка здійснює державне регулювання у сфері ринків фінансових послуг, і Генеральноі прокуратури України, до єдиного реєстру досудових розслідувань у 2016 році за порушення законодавства у сфері діяльності кредитних спілок внесено відомості за 408 фактами протиправної діяльності цими установами. Як правило, ці кредитні спілки працювали за схемами побудови «фінансових пірамід».

За невиконання вимог розпоряджень Національної комісії, яка здійснює державне регулювання у сфері ринків фінансових послуг щодо зобов'язання порушника вжити заходів для усунення порушення та/або вжиття заходів для усунення причин, які сприяли вчиненню порушення, у 2016 році було складено 20 актів про правопорушення учасників кредитного ринку. Крім того, за результатами розгляду звернень громадян у 2016 році складено 37 актів про правопорушення, вчинені на ринку фінансових послуг по кредитних спілках.

Ключові слова: небанківська фінансова установа, кредитна спілка, фінансові послуги, правопорушення, спеціально-кримінологічне запобігання, Національна поліція України.

В статье охарактеризованы рынки финансовых услуг, выделены типичные правонарушения, которые совершаются при осуществлении деятельности кредитными союзами. С целью выявления определенных правонарушений автором охарактеризована деятельность подразделений по защите экономики Национальной полиции, по своевре менному разоблачению злоупотреблений, совершаемых должностными лицами кредитного союза, проверке и анализу их деятельности.

Сегодня наблюдается слабый контроль со стороны государства за функционированием кредитных союзов, что является одним из факторов осуществления ими незаконной деятельности. По данным Национальной комиссии,

Купрієнко В. М., 2019 осуществляющей государственное регулирование в сфере рынков финансовых услуг, и Генеральной прокуратуры Украины, в Единый реестр досудебных расследований в 2016 году за нарушение законодательства в сфере деятельности кредитных союзов были внесены сведения по 408 фактам противоправной деятельности этими учреждениями. Как правило, эти кредитные союзы работали по схемам построения «финансовых пирамид».

За невыполнение требований предписаний Национальной комиссии, осуществляющей государственное регулирование в сфере рынков финансовых услуг, относительно обязательства нарушителя принять меры для устранения нарушения и/или принятия мер по устранению причин, способствовавших совершению нарушения, в 2016 году составлено 20 актов о правонарушениях участников кредитного рынка. Кроме того, по результатам рассмотрения обращений граждан в 2016 году составлено 37 актов о правонарушениях, совершенных на рынке финансовых услуг по кредитным союзам.

Ключевые слова: небанковское финансовое учреждение, кредитный союз, финансовые услуги, правонарушения, специально-криминологическое предупреждение, Национальная полиция Украины.

The article describes the characteristics of the financial services market, which distinguishes typical offenses committed by credit unions. In order to identify the identified offenses, the author describes the activities of the National Police's Economy Protection Units regarding the timely disclosure of abuse committed by credit union officials, inspections and analysis of their activities. The article describes the characteristics of the financial services market, which distinguishes typical offenses committed by credit unions. In order to identify the identified offenses, the author describes the activities of the National Police's Economy Protection Units regarding the timely disclosure of abuse committed by credit union officials, inspections and analysis of their activities.

At present, there is a weak control by the state on the functioning of credit unions, which is one of the factors of their illegal activity. According to the National Commission for State Regulation of Financial Services Markets and the Prosecutor General's Office of Ukraine, to the Unified Register of Pre-trial Investigations in 2016, for violation of legislation in the field of credit unions, information was provided on 408 facts of illegal activity by these institutions. As a rule, these credit unions worked under the schemes of construction of "financial pyramids".

For failure to comply with the requirements of the regulations of the National Commission for State Regulation in the Financial Services Markets regarding the obligation of the offender to take measures to eliminate the violation and / or take measures to eliminate the reasons that contributed to the violation, in 201620 acts of offense to credit market participants. In addition, according to the results of consideration of citizens' appeals in 2016, 37 acts on offenses committed in the market of financial services on credit unions were drawn up. 
The basis of the security strategy in the financial markets is the development of legal measures, because the current state of legislative regulation of crime prevention is characterized by imperfection and imbalance of acts of all levels, lack of an officially recognized concept of development of the legal framework relating to the organization and functioning of the anticrime system, unity of subjects, unjustified duplication of their individual functions, insufficient level of legal support for interactions $J$ coordination of law enforcement and other government agencies.

Key words: non-banking financial institutions, credit union, financial services, offenses, special-criminological prevention, National Police of Ukraine.

Постановка проблеми та іï актуальність. Розв'язання проблем відкритості, гласності, публічності державної влади $\epsilon$ одним із ключових факторів подальшого укорінення в Україні демократичних принципів, побудови цивілізованих норм державоутворення, стає основою формування нової політичної культури. Дотримання принципів транспорентності $€$ необхідною умовою забезпечення конституційних прав громадян на інформацію та участь в управлінні державними справами. Задоволення суспільного запиту на створення ефективних механізмів комунікації між владою та суспільством стає запорукою відтворення дієздатних владних інститутів, а врахування громадської думки - дієвим запобіжником прийняття незрозумілих, непрофесійних та упереджених управлінських рішень.

Останнім часом кількість новостворених кредитних спілок різко скоротилася, при цьому кількість їх відособлених підрозділів збільшилась. Ця тенденція пов'язана з тим, що кредитні спілки почали розширювати мережу своїх філій. Державне регулювання на ринках фінансових послуг спрямоване на досягнення системної стабільності шляхом контролю за дотриманням небанківськими фінансовими установами визначених норм і правил, у тому числі щодо реєстрації та ліцензування, наявності необхідних фінансових ресурсів (капіталу, ліквідності тощо), кваліфікованого персоналу, обмеження ризиків під час провадження діяльності, розкриття інформації тощо.

Виклад основного матеріалу. Основним спеціальним уповноваженим органом виконавчої влади, наділеним правом регулювання та нагляду за діяльністю ринку небанківських фінансових послуг, вважається Нацкомфінпослуг (далі - Національна комісія, що здійснює державне регулювання у сфері ринків фінансових послуг). Вона розробляє низку регуляторних актів, спрямованих на забезпечення належного функціонування ринку небанківських фінансових послуг. За час роботи Нацкомфінпослуг капітал кредитних спілок збільшився майже у 6 разів, а резервний капітал - ключовий складник капіталу - майже в 12 разів. За даними станом на 2016 рік ставки за кредитами у кредитних спілках залишалися вкрай високими. На відміну від банків, кредитні спілки менше маневрені: у них немає диверсифікованих джерел залучення коштів, доступу до довгих і дешевих ресурсів і можливостей оптимізації своїх витрат [1].

Крім того, депозитні внески у кредитні спілки натепер більш прибуткові, ніж банківські внески. Однак вкладення у кредитні спілки традиційно є більш ризикованими, ніж банківські депозити. Ці установи практично не мають можливостей гарантувати повернення внесків своїм членам. Кількість кредитних спілок, які пропонують своїм членам страхувати ризик неповернення депозиту, складає не більше 2-3\% від загальної кількості. Відповідно до даних Нацкомфінпослуг за 2016 рік, 45\% кредитних спілок мають активи, розмір яких менше 500 тис. грн [1].

Нині спостерігається слабкий контроль із боку держави за функціонуванням кредитних спілок, що $є$ одним із чинників провадження ними незаконної діяльності. За даними Нацкомфінпослуг і Генеральної прокуратури України, до Єдиного реєстру досудових розслідувань у 2016 році за порушення законодавства у сфері діяльності кредитних спілок було внесено відомості за 78 фактами протиправної діяльності цими установами. Як правило, ці кредитні спілки працювали за схемами побудови «фінансових пірамід» [2; 3].

Хоча кредитні спілки й функціонують на ринку фінансових послуг 15 років, ефективна система, яка б гарантувала безпеку паїв у кредитних спілках, в Україні дотепер не створена. Єдина діюча форма гарантії вкладень пайовиків спілок - це стабілізаційний фонд, створений на громадських засадах членами Всеукраїнської асоціації кредитних спілок України. Цей фонд формується за рахунок добровільних внесків самих спілок (15\% від суми приросту активів за рік) і призначений для їх фінансової санації. Водночас розмір цього фонду (400 тис. грн) не відповідає активам середньої спілки, тобто загальноприйнятим у світовій практиці нормам [4, с. 214].

Типовими правопорушеннями, які вчинюються при провадженні діяльності кредитними спілками, $\epsilon$ :

- заволодіння майном кредитної спілки (грошовими коштами членів кредитної спілки) шляхом зловживання службовим становищем головою правління (його заступниками), головним бухгалтером шляхом підробки кредитних договорів, видаткових ордерів, квитанцій і заяв на одержання кредиту від імені громадян (на їх паспорти), які насправді зазначені кредити не отримували, а також використання одержаних злочинним шляхом коштів на власні потреби службових осіб кредитної спілки. Нерідко керівники кредитної спілки через третіх осіб обманним шляхом залучають паспорти фізичних осіб. Використовуючи паспортні дані реальних осіб і підроблені довідки про їх доходи, вони формують пакет документів, необхідних для отримання кредиту в кредитній спілці;

- оформлення службовими особами кредитної спілки кредитів на підставних осіб і придбання винними особами на ці грошові кошти товарів для перепродажу та отримання прибутку;

- привласнення коштів членів кредитної спілки, які знаходяться на депозитних рахунках кредитної спілки;

- кредитування шляхом зловживання службовим становищем керівництвом кредитної спілки аффільованих осіб на непрозорих і незрозумілих умовах за рахунок вкладників;

- проведення діяльності кредитною спілкою на ринку фінансових послуг за умови анулювання ліцензії на право провадження такої діяльності (анулювання рішення Нацкомфінпослуг про реєстрацію кредитної спілки як фінансової установи, позбавлення ліцензії кредитної спілки на залучення внесків членів спілки);

- проведення діяльності кредитною спілкою без державної реєстрації як фінансової установи; 
- надання кредитною спілкою недостовірної інформації до Державного реєстру фінансових установ (фальсифікація чи викривлення інформації, яка була подана кредитною спілкою на момент їі державної реєстрації);

- необґрунтоване завищення ставок за окремими депозитами кредитної спілки;

- незаконне здійснення посадовими особами кредитної спілки нарахувань і видачі виплат (відсотків) на додаткові пайові внески членам кредитної спілки, не маючи на те відповідних доходів;

- укладання в кредитній спілці договорів, у яких посадовими особами кредитної спілки застосовуються малозрозумілі терміни з метою зниження суми виплачуваних потенційним клієнтам відсотків. Наприклад, громадяни можуть підписувати в кредитних спілках договори, в яких вказується, що відсотки їм нараховуються у так званих «електронних кредитних балах». На момент укладання договору цей бал може дорівнювати наприклад 5 грн, а трохи пізніше загальні збори спілки (на які не запрошуються потерпілі) приймають рішення, що ці бали складають лише 1 коп.;

- штучне заниження службовими особами кредитної спілки обсягу своїх капіталів з метою отримання законодавчо наданого права відмовити клієнту у видачі кредиту;

- нарахування службовими особами кредитної спілки відсотків не на залишок, а на всю суму наданого кредиту без урахування сум, які вже були повернені вкладниками [5, с. 27-28];

- продаж кредитною спілкою житла тільки через «свої» агентства нерухомості. При цьому до договору вноситься особливий пункт, згідно з яким підбір і покупка об'єкта нерухомості здійснюється тільки через агентство нерухомості, з яким спілка уклала відповідні договори. Це означає, що клієнт не зможе купити ту квартиру, яку він підібрав сам, оскільки за договором він повинен купувати житло лише через агентство, пов'язане зі спілкою. Як правило, така квартира коштуватиме на 5-10\% дорожче;

- створення засновниками кредитної спілки юридичних компаній, послугами яких зобов'язані користуватися клієнти кредитної спілки. У результаті службові особи кредитної спілки заробляють додаткові, «невраховані» комісійні на наданих фактично ними юридичних послугах. Адже до договору з клієнтами кредитної спілки вноситься пункт, відповідно до якого правоустановчі документи продавця на об'єкт нерухомості, який збирається придбати клієнт, надаються тільки тій юридичній компанії, з якою спілка уклала договір. Як правило, такі юридичні компанії створені засновниками кредитної спілки. У результаті реальна ціна кредиту може складати вже $27-30 \%$ річних, а не $7 \%$, як зазначено у рекламі кредитної спілки [6, с. 327-328];

- функціонування кредитної спілки за схемою побудови «фінансових пірамід» (наприклад, коли пайовик-член КС може розраховувати на квартиру в кредит за умови, що він приведе ще двох-трьох учасників кредитної спілки та підвищить капіталізацію кредитної спілки на \$200-300);

- здійснення фінансовою установою операцій із залучення грошових внесків від населення, мотивуючи це провадженням діяльності як кредитної спілки всупереч вимогам чинного законодавства, не маючи відповідної ліцензії, порушуючи вимоги Закону України «Про фінансові послуги та державне регулювання ринків фінансових послуг» [7];

- надання кредитною спілкою недостовірної інформації до Нацкомфінпослуг;

- порушення прав членів кредитної спілки при голосуванні на загальних зборах залежно від розміру їх пайового та інших внесків;

- неінформування або несвоєчасне інформування членів кредитної спілки з питань власної діяльності, неознайомлення з протоколами загальних зборів і засідань інших органів управління кредитної спілки;

- заснування кредитною спілкою суб'єкта (суб'єктів) підприємницької діяльності (крім місцевого кооперативного банку) як на території України, так і за її межами;

- невідповідність чисельності засновників (членів) кредитної спілки нормативно визначеним нормам (ця чисельність менше ніж 50 осіб);

- неповернення у разі припинення членства фізичної особи у кредитній спілці обов'язкового пайового та інших внесків, крім вступного внеску;

- порушення порядку та терміну скликання чергових загальних зборів членів кредитної спілки;

- обрання членами спостережної ради кредитної спілки осіб, які перебувають у трудових відносинах із кредитною спілкою;

- незаконна участь члена кредитного комітету у прийнятті рішення про надання йому як члену кредитної спілки кредиту;

- входження до складу ревізійної комісії членів спостережної ради, правління, кредитного комітету та осіб, які перебувають із кредитною спілкою у трудових відносинах;

- розмір капіталу кредитної спілки менший, ніж 10 відсотків від суми її загальних зобов'язань;

- недосягнення резервним капіталом кредитної спілки величини, яка дорівнює 15\% від суми їі активів;

- неформування кредитною спілкою резерву забезпечення покриття втрат від неповернених позичок;

- перевищення нормативно встановленого розміру кредиту, наданого одному члену кредитної спілки, який перевищує 20 відсотків від капіталу кредитної спілки;

- перевищення нормативно встановленого розміру зобов'язань кредитної спілки перед одним своїм членом, який перевищує 10 відсотків від загальних зобов'язань кредитної спілки;

- перевищення нормативно встановленого розміру загальної суми залучених коштів, у тому числі кредиту, який перевищує 50\% вартості загальних зобов'язань і капіталу кредитної спілки на момент залучення;

- перевищення доходності додаткових пайових членських внесків більш ніж у два рази доходності внесків (вкладів) членів кредитної спілки на депозитних рахунках;

- порушення службовими особами кредитної спілки таємниці збереження відомостей щодо рахунків, внесків та інших фінансових операцій, здійснених членами кредитної спілки;

- корупційні діяння працівників (держслужбовців) Нацкомфінпослуг, які вносять неправдиві дані під час перевірки діяльності певної кредитної спілки на користь службових осіб цієї кредитної спілки;

- шахрайські дії вкладників кредитної спілки, які незаконно отримують на підставі підроблених документів кредити у відповідній кредитній спілці. 

та науково-методичне забезпечення

3 метою виявлення зазначених правопорушень, які вчиняються посадовими особами кредитної спілки, працівникам Національної поліції із захисту економіки необхідно перевірити та проаналізувати такі документи:

- свідоцтво про державну реєстрацію кредитної спілки як фінансової установи у Департаменті регулювання та нагляду за кредитними установами Нацкомфінпослуг;

- ліцензію на провадження діяльності із залучення внесків від населення (якщо організація приймає такі внески);

- статут кредитної спілки [5, с. 33].

Із статуту кредитної спілки можна дізнатися про такі особливості її функціонування:

- мету створення і завдання кредитної спілки;

- ознаку членства у кредитній спілці;

- порядок утворення та діяльності органів управління кредитної спілки, порядок утворення філій і відділень, їх повноваження;

- права та обов'язки членів кредитної спілки;

- умови і порядок вступу до кредитної спілки, порядок припинення членства у кредитній спілці;

- джерела надходження i порядок використання коштів та іншого майна кредитної спілки, в тому числі порядок і умови надання кредитів членам кредитної спілки, порядок формування та використання фондів, утворюваних спілкою;

- порядок припинення діяльності кредитної спілки та вирішення майнових питань у зв'язку з їі ліквідацією (реорганізацією); спілки;

- порядок покриття можливих збитків кредитної

- порядок розподілу доходів кредитної спілки [8, с. 211];

- список засновників кредитної спілки (реєстр осіб, які брали участь в установчих зборах). У реєстрі мають бути обов'язково зазначені прізвище, ім'я та по батькові особи, дані її паспорта або документа, який його замінює (а для іноземців та осіб без громадянства, які постійно проживають в Україні, - дані національного паспорта або документа, який його замінює), адреса. Дані про особу повинні бути засвідчені її особистим підписом;

- річну фінансову звітність про результати діяльності кредитної спілки (річні баланси, звіт про доходи і витрати), затверджену загальними зборами кредитної спілки, де особливу увагу слід звернути на фінансовий стан кредитної спілки, а саме на отримані нею доходи і витрати;

- касові книги кредитної спілки, де відображаються прийняті від членів кредитної спілки платежі;

- аудиторський висновок щодо річної фінансової звітності кредитної спілки;

- протоколи засідань органів управління (загальних зборів членів кредитної спілки, спостережної ради, ревізійної комісії, кредитного комітету та правління, наприклад звіти спостережної ради, правління та кредитного комітету, висновки ревізійної комісії) кредитної спілки та інші документи щодо діяльності кредитної спілки. Так, рішення загальних зборів членів кредитної спілки повинні бути оформлені протоколом, підписаним головою та секретарем цих зборів;

- економічну обґрунтованість зареєстрованого розміру капіталу кредитної спілки. Як відомо, ст. 21
Закону України «Про кредитні спілки» [9] містить обмеження щодо діяльності кредитної спілки: кредитна спілка не може видавати кредит, сума якого складає понад 20\% капіталу кредитної спілки. На практиці це дозволяє службовим особам кредитної спілки штучно занижувати обсяг своїх капіталів, щоб у подальшому мати законне право відмовити клієнту у видачі кредиту. В результаті цих дій кредитні спілки одержують можливість якомога довше використовувати на свою користь грошові кошти клієнта;

- укладені кредитною спілкою договори з вкладниками про пайові внески;

- укладені з членами кредитної спілки договори про надання кредиту;

- опубліковані повідомлення про скликання чергових загальних зборів КС;

- прийняті рішення кредитного комітету про надання кредитів, проаналізувати їх обґрунтованість;

- затверджені кошторис і штатний розпис кредитної спілки;

- затверджене спостережною радою кредитної спілки положення про структурні підрозділи кредитної спілки;

- положенняпрокредитнийкомітеткредитноїспілки;

- укладенікредитноюспілкоюдоговоритаіншіугоди;

- розглянуті кредитним комітетом кредитної спілки заяви членів кредитної спілки про надання кредитів i прийняті рішення з цих питань;

- результати проведених ревізійною комісією перевірок діяльності КС, наприклад складений ревізійною комісією висновок за річними звітами про результати діяльності кредитної спілки [10, с. 145-146].

3 метою своєчасного викриття зловживань, які вчиняються службовими особами кредитної спілки, працівникам Національної поліції передусім необхідно звернути увагу на розмір капіталу кредитної спілки; рівень простроченої кредиторської заборгованості (уніфікованої методики визначення такої заборгованості немає, кожна кредитна спілка визначає їі по-своєму залежно від того, які види кредитів вона надає); види застави (першочергову увагу слід звернути на кредитні спілки, які кредитують, наприклад, під майбутній урожай, а не під заставу ліквідної нерухомості).

Слід також звернути увагу на види кредитів, які надаються кредитною спілкою, на величину сформованого кредитною спілкою резерву забезпечення покриття втрат від неповернених позичок; на розмір кредиту, наданого одному члену кредитної спілки (який не повинен перевищувати 20\% від капіталу кредитної спілки); на розмір зобов'язань кредитної спілки перед одним своїм членом (який не повинен перевищувати $10 \%$ від загальних зобов'язань кредитної спілки); на розмір загальної суми залучених коштів, у тому числі кредиту (який не повинен перевищувати 50\% вартості загальних зобов' язань і капіталу кредитної спілки на момент залучення). При цьому в кредитній спілці кошти, що належать членам кредитної спілки, мають обліковуватися окремо. Крім того, ці кошти повинні використовуватися для надання кредитів членам кредитної спілки, а у разі наявності тимчасово вільних коштів членів кредитної спілки вони можуть розміщуватися спілкою на депозитних рахунках в установах банків, які мають ліцензію на право роботи із вкладами громадян, і в об'єднаній кредитній спілці, а також у державні цінні папери. 
Висновки. Таким чином, в основі стратегії забезпечення безпеки на фінансових ринках лежить розроблення заходів правового характеру, адже сучасний стан законодавчого регулювання попередження правопорушень характеризується недосконалістю та розбалансованістю актів усіх рівнів, відсутністю офіційно визнаної концепції розвитку нормативно-правової бази, яка стосується організації і функціонування системи боротьби з правопорушеннями, роз'єднаністю суб'єктів, невиправданим дублюванням окремих їх функцій, недостатнім рівнем правового забезпечення взаємодії й координації правоохоронних та інших державних органів.

\section{Література}

1. Кредитні спілки, що порушують законодавство, будуть виключені з Державного реєстру фінансових установ. Інформація Національної комісії, що здійснює державне регулювання у сфері ринків фінансових послуг. 2017. URL: http://nfp.gov.ua/.

2. Публічний звіт про діяльність Національної комісії, що здійснює державне регулювання у сфері ринків фінансових послуг, за 2016 рік. URL: http://nfp.gov.ua/content/ rzviti-nackomfinposlug.html.

3. Про зареєстровані кримінальні правопорушення та результати їх досудового розслідування. Генеральна прокуратура України. URL: http://www.gp.gov.ua/ua/ stat.html.
4. Чернєй В.В. Кримінально-правові та кримінологічні засади запобігання злочинам у сфері діяльності небанківських фінансових установ в Україні : монографія. Київ, 2014. 456 C.

5. Виявлення та запобігання злочинам, що вчинюються на ринку діяльності небанківських фінансових установ : метод. рек. Київ : Нац. акад. внутр. справ, 2014. 56 с.

6. Чернявський С.С. Фінансове шахрайство: методологічні засади розслідування : монографія. Київ : «Хай-ТекПрес», 2010. 624 c.

7. Про фінансові послуги та державне регулювання ринків фінансових послуг : Закон України від 12 липня 2001 року № 2664-III. Верховна Рада України. URL: http: / / zakon2.rada.gov.ua/laws/show/254\%D0\%BA/ 96-\%D0\%B2\%D1\%80.

8. Кредитні спілки в Україні: основні засади діяльності : навч. посіб. / за заг. ред. А.Я. Оленчика. Київ : УІРФР, 2006. 652 c.

9. Про кредитні спілки : Закон України від 20 грудня 2001 року № 2908-III. Верховна Рада України. URL: http://zakon2.rada.gov.ua.

10. Економічна безпека : навч. посіб. / о.є. Користін та ін. / за ред. О.М. Джужі. Київ : Алерта; КНТ; Центр учбової л-ри, 2010. 368 с.

Купрієнко В. М., здобувач кафедри кримінального права, кримінології, цивільного та господарського права ВНЗ «Національна академія управління» 